\title{
Comparative Judicial Emergency Administration during Pandemic Covid-19
}

\author{
Ibnu Sina Chandranegara ${ }^{1}$ \\ ${ }^{1}$ Faculty of Law, University of Muhammadiyah Jakarta, Jakarta, Indonesia \\ Correspondence: Ibnu Sina Chandranegara, Faculty of Law, University of Muhammadiyah Jakarta, Jakarta, Jl. \\ K.H. Ahmad Dahlan, Jakarta Selatan, Jakarta 15419, Indonesia. Tel: +62-859-5988-7782. E-mail: \\ ibnusinach@umj.ac.id
}

Received: December 2, 2020

Accepted: December 21, $2020 \quad$ Online Published: December 22, 2020

doi:10.5539/jpl.v14n2p27

URL: https://doi.org/10.5539/jpl.v14n2p27

\begin{abstract}
The Decree of a state of emergency affects not only the executive and legislative branches but also the judiciary. The Covid-19 Pandemic in various countries has both direct and indirect effects on the judiciary, especially in the performance of its duties and functions. This article is to found out the answer of two research question first, how court administration in the United States and Indonesia responds to the Covid-19 pandemic emergency and second, how is its reflection in on optimizing access to justice for court administration even under in the state of emergencies to the pandemic Covid -19. This study uses the comparative method by a study on legal material and practice of judicial emergency in other countries to take the best material and approach to provides advice that needs to be avoided in Indonesian Judiciary. This article has a novelty that legal material in the Judiciary act and procedural law books so limiting delegation to set supplementary regulations for each court and creating potential uniformity for emergency policy in the judiciary.
\end{abstract}

Keywords: court administration, judicial emergency, procedural law

\section{Introduction}

In the practice of state administration generally understood in two circumstances, first, the state is in a normal condition, and secondly, the state is in an emergency. Under the normal state, the system of legal norms imposed is based on the Constitution and the legal system that is intended to regulate the administration of the state under normal circumstances. However, if the state is in an abnormal condition, or an emergency, the exercise of powers and legal instruments is an emergency and allows for the exclusion of the fulfilment of certain human rights. David Davis said Under the Constitution, the government has all the powers given to it that are required to sustain its life. (Bader \& Williams, 2009). It shows that the government, in terms of the Indonesian context is that the President has the power to exclude the application of ordinary law by enacting emergency laws. In principle, emergencies can be divided into two things: first, crises caused by civil or military conditions, secondly, crises caused by the threat to human health (Sheeran, 2013). In the first context, the President will take a series of actions by imposing an emergency based on legal principles well know as salus populi suprema lex (public interest is the highest law) (Hunter, 2017).

In contrast, in the second context, the President will impose a series of actions to save the health of his citizens or with the necessary legal principles, salus populi suprema lex esto (public health is the highest law) (Arde-Acquah, 2015). The question is how judiciary especially their administration aspect to responds health emergencies situation. Judiciary is an essential branch to balance executive and legislative not only in normal circumstances but in emergencies. It is due to the potential for many policies issued, especially in the context of health emergencies which could potentially be an abuse of power or violation of citizens constitutional rights (Chandranegara, 2020b). Some even found that in some country in Southeast Asia often created authoritarian patterns of government when handling Covid-19 (Chandranegara, 2020a). Therefore, in such a condition, making judicial independent and still providing justice services needs to be considered (Pimentel, 2015). This article is to answer two research question first, how court administration in the United States and Indonesia responds to the Covid-19 pandemic emergency and second, how is its reflection in on optimizing access to justice for court administration even under in the state of emergencies to the pandemic Covid -19 . 


\section{Method}

This research is a normative juridical study with comparative law methods. By using a comparative method, this article uses court administration policy the United States in response to the Covid-19 pandemic situation and how it reflects on administration court in Indonesia. Referring to Mark Rheinstein who argued that the comparison of law is the explanation of various matters regarding how to treat law scientifically using particular classifications or analytic descriptions of the use of one or more positive legal systems (Rheinstein, 1968). Therefore, the scope of the data used is secondary data which includes primary and secondary legal material in the form of regulations relating to judicial responses in the United States to the Covid-19 Pandemic. Secondary data obtained through literature study. Data analysis was carried out by systematizing the data, and subsequently, the data was used to seek benefits for the judiciary in responding to uniform conditions in Indonesia.

\section{Results and Discussion}

\subsection{How Court Administration in the US responds Covid-19}

The Covid-19 Pandemic impacted much of the lives of the United States, including all levels of government. The Supreme Court took the unprecedented measure on March 16, 2020, to postpone an oral argument session scheduled for at least the next two weeks. (Livni, 2020). In 2012, when Sandy's Hurricane closed all offices in Washington state, the Supreme Court also postponed the oral argument procedure session. In its growth even expanded when other government agencies closed due to snowstorms in that year (Liptak, 2012). The Supreme Court recently declared that in response to COVID-19, judges should take action in compliance with the recommended public health precautions. Because of the changing conditions, the Court will review the possibilities of reprogramming certain cases in due course. The first thing that occurred is not considered to be this sort of delay. (Gerstein, 2020). In reaction to the Spanish flu outbreak, courts in the United States deferred the scheduled oral argument in October 1918. In reaction to the plague of yellow fever, the court also shortened the duration of the trial period at the proof hearings in August 1793 and August 1798. (Walsh, 2020). Regardless of the current Supreme Court decision in response to the Corona Virus Pandemic, Austin Sarat criticized it as he says as someone who has studied law and tragedy, he concludes that when the court needs to respond to situations such as the Covid19 crisis, the court should concentrate less on the precedent set, and more on their readiness and capacity to continue to discharge their obligations under the Constitution. The courts are discussing some of today's most important legal issues in the nation. It has implications for residents and elected officials who require dispute resolution and authoritative interpretations of the law to avoid their work. (Sarat, 2020).

Courts across the United States, outside of the Supreme Court, are rapidly responding to the ongoing crisis. By the start of March 2020. A task force for 94 district courts and 13 district courts to exchange knowledge and advice was created by the federal court system. (Sarat, 2020). Representatives from the US Marshals Service are involved in the task force (Libowitz, 2020), which helps provide protection for judges and courts and Federal Occupational Health officials, who oversee the work safety of workers (Sarat, 2020). The courts are designing their ways to proceed because the task force has not yet provided recommendations for all federal justice. The Northern California District closed four federal courthouses to the public on March 17, 2020, and all jury trials and criminal cases across the district were adjourned until May 1, 2020. (Gerstein, 2020). And then by phone or video call, the trials will be performed. This scenario is the federal court's first mass closure since the Covid-19 emergency started. (Gerstein, 2020). At the same time, those who had extended deadlines for archiving documents or declared they would hold hearings via video conferencing continued to do business as normal in the North Ohio District. (Livni, 2020).

\subsection{Judicial Emergency Act of 2004}

Judicial emergencies are governed by the Judicial Emergency Act of 2004 in the United States. This law requires judicial officials, under some cases, to be allowed to declare a judicial emergency. The Chief Justice, the State Supreme Court, the Chief Judge of the Trial Court, the Chief Judge of the Circuit Court, the State High Court or the day-to-day executor or executor of the Head of the Court are official judicial officers. (Judicial Emergency Act, 2004). In addition, a judicial emergency means an emergency declared by the governor with regard to public health emergencies as specified in state or federal law; local emergencies as defined in state law; or other severe emergencies; and when designated judicial officials decide that such emergencies seriously jeopardize or hinder the normal functioning of the justice system, the ability of individuals to do so (Judicial Emergency Act, 2004). Based on these laws, the following is a summary of judicial policies in each state in terms of conducting judicial operations during the Covid-19 pandemic: 
Table 1. Recapitulation judicial order in judicial emergency in the United States as of April 6, 2020

\begin{tabular}{|c|c|}
\hline State & Policy \\
\hline Arkansas & $\begin{array}{l}\text { Any summonses to serve in jury panels for individuals are postponed until } 30 \text { June (Supreme } \\
\text { Court of Arkansas, 2020). }\end{array}$ \\
\hline Connecticut & $\begin{array}{l}\text { On Tuesday, April 7, 2020, all remaining open courthouses will be closed. Starting on Tuesday, } \\
\text { April 14, 2020, all courthouses will be closed until further notice on Tuesdays and Thursdays. } \\
\text { (State of Connecticut Judicial Branch, 2020). }\end{array}$ \\
\hline Illinois & $\begin{array}{l}\text { The Supreme Court orders that before further orders from the Supreme Court, the Chief Judges } \\
\text { of each circuit can begin trials. (Supreme Court of Illinois, 2020). }\end{array}$ \\
\hline Kansas & $\begin{array}{l}\text { the Chief Judge of each circuit can begin proceedings until the Supreme Court has issued further } \\
\text { orders (Supreme Court of The State of Kansas, 2020). }\end{array}$ \\
\hline North Carolina & $\begin{array}{l}\text { Limits on the trials in person and suspensions of jury proceedings extended until } 1 \text { June. (North } \\
\text { Carolina Judicial Branch, 2020). }\end{array}$ \\
\hline Massachusetts & $\begin{array}{l}\text { The limits on in-person hearings and the suspension of jury proceedings have been extended } \\
\text { until } 4 \text { May. The order of the Supreme Judicial Court specifies that "pre-trial detainees who have } \\
\text { not been charged with an excluded offence as outlined in Appendix A are titled to a rebuttable } \\
\text { presumption of release on personal recognizance, and a hearing within two business days of } \\
\text { filing a motion for reconsideration of the bail and release ... " (Commonwealth of Massachusetts, } \\
\text { 2020) }\end{array}$ \\
\hline Pennsylvania & $\begin{array}{l}\text { The Supreme Court refuses to order the release of inmates/prisoners. Directs'President Judges } \\
\text { in each judicial district to work with relevant county stakeholders to ensure that the county } \\
\text { correctional institutions in their districts mitigate the threat of COVID-19 apply the } \\
\text { recommendations of public health officials in correctional and detention facilities, including the } \\
\text { CDC Interim Guidance on Coronavirus Disease Control } 2019 \text { (COVID-19) (March 23, 2) } \\
\text { (Supreme Court of Pennsylvania, 2020) }\end{array}$ \\
\hline Rhode Island & $\begin{array}{l}\text { An expedited hearing for } 52 \text { prisoners was required by the Supreme Court to reduce the state } \\
\text { prison population. (Supreme Court of Rhode Island, 2020). }\end{array}$ \\
\hline South Carolina & $\begin{array}{l}\text { Limitations on in-person hearings and suspension of jury trials levied by the Supreme Court } \\
\text { until further notice/order (Supreme Court of South Carolina, 2020). }\end{array}$ \\
\hline $\begin{array}{l}\text { Northern Mariana Islands } \\
\text { (territories) }\end{array}$ & $\begin{array}{l}\text { Limitations on in-person trials and suspension of jury proceedings up to } 5 \text { June (Supreme Court } \\
\text { of The Commonwealth of The Northern Mariana Islands, 2020). }\end{array}$ \\
\hline West Virginia & $\begin{array}{l}\text { Limitations on in-person hearings and suspensions of jury trials were extended until } 4 \text { May. } \\
\text { (Supreme Court of Appeals of West Virginia, 2020). }\end{array}$ \\
\hline Alabama & $\begin{array}{l}\text { Limitations on in-person proceedings and suspension of jury proceedings were extended to } 30 \\
\text { April (Supreme Court of Alabama, 2020). }\end{array}$ \\
\hline Alaska & $\begin{array}{l}\text { Except for those priority hearings listed in the Special Order of the Chief Justice, all trial court } \\
\text { proceedings and civil marriage ceremonies are suspended until May 1, 2020. Civil examples. } \\
\text { By telephone or videoconference, all lawyers, parties, witnesses, and other participants must } \\
\text { appear. Criminal cases: All counsel, parties, witnesses and other individuals, except for } \\
\text { evidentiary hearings and sentencing, shall appear by telephone or video conference. (Supreme } \\
\text { Court of The State of Alaska, 2020). }\end{array}$ \\
\hline Arizona & $\begin{array}{l}\text { All in-person hearings in all Arizona appeal, superior, justice and municipal courts and before } \\
\text { the presiding disciplinary judge are directed to be avoided to the fullest extent possible, until } \\
\text { further order of this court, consistent with core constitutional rights. It is also directed to } \\
\text { reschedule the panelling of new petit juries scheduled for March 18, 2020, until April 17, } 2020 \text {. } \\
\text { (Supreme Court of the State of Arizona, 2020). }\end{array}$ \\
\hline California & $\begin{array}{l}\text { Both jury trials will be postponed for } 60 \text { days and will resume. Courts may hold a trial at an } \\
\text { earlier date upon discovery of a good cause or where applicable, by the use of remote } \\
\text { technology. (Supreme Court of California, 2020). }\end{array}$ \\
\hline Colorado & $\begin{array}{l}\text { Effective immediately, all jury cases in state courts are postponed until May 15, 2020, except } \\
\text { for jury calls for criminal trials facing imminent speedy trial deadlines, again except cases with } \\
\text { close speedy trial deadlines. (Supreme Court of Colorado, 2020). }\end{array}$ \\
\hline Indiana & $\begin{array}{l}\text { None, Local: Emergency applications for Local Courts Administrative Orders to Operate (the } \\
\text { State of Indiana, 2020). }\end{array}$ \\
\hline Iowa & $\begin{array}{l}\text { Civil trials suspended to April 20. Criminal trials not yet commenced adjourned to April } 20 \\
\text { (Iowa Supreme Court, 2020). }\end{array}$ \\
\hline
\end{tabular}


\begin{tabular}{ll}
\hline Kentucky & The Supreme Court passes new amendments requiring the prohibition of in-person court \\
hearings and extends the restrictions until 24 April (Hiatt, 2020). \\
Both civil and criminal jury trials scheduled to begin in any state court in Louisiana between \\
the date of this order and March 27, 2020, will have to be reset by local order no earlier than \\
March 30, 2020. Civil and criminal jury trials that are in progress as of March 13, 2020, can \\
proceed to a conclusion, in the discretion of the local court (Supreme Court of Louisiana, 2020). \\
Except for certain activities on March 13 and continuing through May 1, 2020, all in-person \\
court appearances for family, civil, and criminal dockets are delayed. (State of Maine Judicial \\
Branch, 2020). \\
Pending further orders from the Chief Judge of the Court of Appeals, all other matters scheduled \\
to be heard between 16 March 2020 and 1 May 2020 shall be deferred. All courts of the \\
Maryland Judiciary, of the Judicial Offices, of the Administrative Offices, of the Judiciary Units, \\
of the Secretaries' Offices of the Circuit Courts and the Secretaries' Offices of the District Court, \\
shall be limited to emergency operations and shall be closed with limited exceptions, as defined \\
in this order, from 17 March 2020 until 1 May 2020 or until further notice by the Chief Judge \\
of the District Court. (Court of Appeals of Maryland, 2020).
\end{tabular}

Delaware

The March 16 Judicial Emergency was declared for 30 days. In order to restrict the number of individuals assembling in public court facilities, all trial courts in the State shall have the discretion to extend trials and proceedings in civil and criminal cases for 30 days. (Supreme of Court of the Delaware, 2020).

Florida

During the time beginning Monday, March 16, 2020, through Friday, April 17, 2020, or as given by subsequent orders, all grand jury proceedings, jury selection proceedings, and criminal and civil jury trials are suspended (Supreme Court of Florida, 2020).

Georgia

Declaration of Judicial Emergency. Local judges were left with the decision. The courts should remain open to tackling critical duties, and in particular, the courts should give priority to matters required to safeguard the health, protection and rights of individuals. (Supreme Court of Georgia, 2020)

Hawaii Except for emergency and time-sensitive matters, civil, family and to the extent practicable, criminal dockets will be limited to in-person appearances from Tuesday 17 March 2020 until Thursday 30 April 2020, unless otherwise requested, unless otherwise stated. (Hawai'i State Judiciary, 2020).

Idaho

There is a delay in civil trials until further notice. Judicial courts will be postponed from 25 March 2020 until 30 April 2020. (Supreme Court of the State of Idaho, 2020).

Michigan

$\mathrm{n} / \mathrm{a}$. In support of this purpose, each trial court judge can by order of the Court of Justice, take emergency measures concerning court operations to allow continued service, while at the same time reducing the risk of further transmission of the virus. Subject to legislative and constitutional constraints, such as emergency measures can include...(Supreme Court of Michigan, 2020)

Minnesota

For case types designated as 'Medium Priority' or 'Low Priority' on the Restricted Court Service Case Priority List, all court proceedings will be postponed for 14 days (except for jury proceedings already ongoing or cases where a speedy trial has been requested) No new jury proceedings in these case types should be scheduled for the next 30 days In addition to the statewide order, Court of Minnesota continuing operations should be suspended for the next 30 days. The order takes effect on Monday, 23 March 2020 and is in place for the next 30 days or until the issuance of another order, whichever comes first. (The state of Minnesota in Supreme Court, 2020)

Mississippi Individual judges have the power to monitor general dockets and are allowed to advise their clerks not to give jury summons to jurors that would be returnable before April 13, 2020, at any date. No groupings of more than 50 individuals (Supreme Court of Mississippi, 2020).

Missouri

Restrictions on in-person and jury trials were extended until 1 May. (Supreme Court of Missouri, 2020).

Montana

The Montana Supreme Court's chief justice, Mike McGrath, has ordered all state courts to follow a list of procedures starting Monday. Parties scheduled for trial until April 30 will ask for a postponement to reduce foot traffic in the courtroom. (Montana Supreme Court, 2020).

Nebraska None. Limitations on people with or suspected of having COVID-19(Supreme Court of the State of Nebraska, 2020).

Nevada 
New Hampshire

New Jersey

New Mexico

New York

North Dakota

Ohio

Oklahoma

Oregon

South Dakota

Tennessee

Texas

Utah

Vermont

Virginia

Washington

Wisconsin

Wyoming

Washington, DC (federal district)

Subject to the exceptions in paragraph 4 below, all Circuit, Superior and Supreme Court inperson proceedings shall be suspended from closure on Monday, 16 March 2020 until 6 April 2020. (Supreme Court of New Hampshire, 2020)

There are no in-person Supreme Court cases as of March 18, 2020, and before further notice (except for minimal emergent matters and specific ongoing trials). As many matters as practicable will be handled by telephone or video conference (including case management sessions, motions, and hearings). The grand jury has been dissolved until 26 April. Other times previously postponed or extended have now been extended until 26 April. (Supreme Court of New Jersey, 2020).

Unless there are exceptional circumstances, civil jury trials that have not begun are delayed. Unless rescheduled by a judge, civil non-jury trials will continue. Jury appointments are limited to 25 members. (New Mexico Courts, 2020)

Local: Protection protocols in place.

Concludes ongoing trials, but there are no new trials to proceed. The postponement of all nonessential roles (New York Courts, 2020).

All criminal and civil] jury trials are immediately postponed until April 24, 2020, or until further order from the Supreme Court is issued. (State of North Dakota Courts, 2020).

None (The Supreme Court of Ohio, 2020)

Subject only to statutory restrictions, all non-jury trial settings, hearings, and pre-trial settings should be rescheduled by appointed judges. (Supreme Court of Oklahoma, 2020).

Non-essential trials and the bulk of jury trials have been postponed until June 1. Presiding Judges collaborate with local law enforcement and community corrections to recognize offenders who can be safely released or eligible for parole in their prisons. (Oregon State Courts, 2020).

None ( Supreme Court of State of South Dakota, 2020)

All in-person hearings, including but not limited to municipal, juvenile, general sessions, criminal, and appeal courts, in all state and local courts in Tennessee are suspended from the close of business on Friday, March 13, 2020, to Thursday, April 30, 2020, subject to exceptions. ( Supreme Court of Tennessee, 2020).

$\mathrm{n} / \mathrm{a}$; The order requires local courts to take action by May 8, 2020. (Supreme Court of Texas, 2020).

n/a. Local courts are allowed to take steps consistent with the "Red" plan in the continuity of the operational plan of the state (Supreme Court of Utah, 2020).

Postponement until at least April 15, 2020, of all jury trials for which the jury has not been drawn up (Vermont Supreme Court, 2020).

Restrictions on in-person hearings and jury trials were extended until 26 April. (Supreme Court of Virginia, 2020).

Not until after April 24, 2020, shall all jury trials be suspended. All emergency cases must be heard before 24 April 2020, by telephone, video or other means that do not require in-person attendance, unless this is impossible. All criminal jury trials are postponed until April 24, 2020 (Supreme Court of Washington, 2020)

Orders of the Supreme Court keep on jury trials, stop statewide in-person hearings in favour of phone and video appearances by May 22 (Wisconsin Court System, 2020).

Previous orders have been extended until May 31. On-person hearings and jury trials orders, revised limitations amended and reissued (Supreme Court of Wyoming, 2020).

To the degree that a case form has not been listed below all nonpriority matters scheduled before May 1, 2020, will be rescheduled and new dates set; emergency matters will be heard as scheduled by the court and as set out in the order] (Supreme Court of Washington, DC, 2020).

Based on the recapitulation as described, it can be classified into various policies, including:

\subsubsection{Postponement Except Regarding the Protection of Child Welfare}

Several courts delay the whole trial process except for a few states that continue to carry out judicial processes involving child protection and welfare (Supreme Court of Alabama, 2020). For example, it breaks down in Judicial Order the Florida Courton March 17, 2020, that critical court cases, including but not limited to ... juvenile 
dependencies, shelter hearings; juvenile delinquency, custody hearings; hearings on requests for temporary injunctions relating to the welfare of a person ... shall continue to be performed by all circuit and county courts. Hearings on applications for a temporary emergency guardian to be appointed...(Supreme Court of Florida, 2020)

\subsubsection{Delays Except When It Comes to Protecting Domestic Violence}

Courts that suspend the entire proceeding except for some states that continue give priority to the judicial process that concerns the protection of domestic violence ( Supreme Court of Alabama, 2020). For example, it breaks down in Judicial Order the Alabama Supreme CourtMarch 13, 2020 that Exceptions to this in-person court proceedings suspension include... Proceedings concerning defence from violence... Security orders and temporary injunctions, which otherwise expire between 16 March 2020 and 16 April 2020, are hereby extended until 16 April 2020, unless the court wishes to make an order to the contrary. (National Center for State Courts, 2020)

\subsubsection{Evictions and Foreclosures}

Courts which postpone the entire proceedings except for several states that continue to carry out judicial proceedings concerning Evictions and foreclosures (Court of Appeals of Maryland, 2020). For example, it breaks down in Judicial Order the Pennsylvania Supreme CourtMarch 18, 2020 that In the light of these circumstances, it is further directed that no judge, official or other person employed by the Pennsylvania Judiciary at any level shall carry out an eviction, expulsion or another removal from residence during the time covered by this Order or by a judicial emergency, whichever is longer, based on failure to make rent, a loan or other similar payments. Nothing herein is intended to include demands for possession arising from judgments to be filed by mail entered in landlord-tenant proceedings. Any implementation of the order of control shall, however, remain on or after 3 April 2020, subject to further orders. (National Center for State Courts, 2020)

\subsubsection{The Hearing Process is Completely Deferred}

In this category, in general, many state courts have adjourned the hearing process completely (Supreme Court of Arkansas, 2020). For example, it breaks down in Judicial Order the Arkansas Supreme CourtMarch 17, 2020 that The courts of the State of Arkansas will continue to be available. Nonetheless, the Supreme Court of Arkansas is currently suspending all in-person hearings in all appeals, circuits, and district courts, under the exceptions in this order, under the statutory superintending power of this Court to supervise the administration of the state judicial system. (National Center for State Courts, 2020)

\subsubsection{The Order to Release the Detainee City}

Court to postpone the entire proceedings unless some counties state that continue to carry out the process of judicial orders to release detainees city (mild sanctions). For example, unravelled in Judicial Order the Sacramento High Court, March 25, 2020, that because the parties agree that reducing the population of the Sacramento County Jail System is in the best interest of public health, and under section 4004 of the Penal Code, the court finds reasonable cause to order the Sacramento County Sheriff to use the authority given in section 8658 of the California Government Code and sections 101029 and 120155 of the Health and Safety Code to release all confined persons (March 25, 2020)."

\subsubsection{Orders for the Release of Detained Defendants. (Suspension of Detention)}

Some states adopt a policy of releasing detainees (Supreme Court of Pennsylvania, 2020). Chief Justice of Kentucky Supreme Court (letter) March 20, 2020, that Kentucky's overcrowded prisons urgently need our support as we take proactive measures to ensure social distancing in our judicial facilities. State and national media outlets are sounding the warning about what a COVID-19 outbreak will do to prisoners and prison personnel and the law enforcement officers who come into contact with them. Jails are vulnerable to worse-case situations, just like nursing homes, due to the proximity of individuals and the number of pre-existing conditions... We know what a possible tragedy this might be, and it is our job to work as efficiently as we can with jailers and other county officials to release as many defendants as we can safely.

\subsubsection{Carrying out Justice as Usual but Using Tools. Telehearings and Teleconferencing}

Some Courts in some states do not even delay the judicial process or any stage but instead use telehearing and teleconference (Supreme Court of Arkansas, 2020). For example, it is unravelled in Judicial Order the Arkansas Supreme CourtMarch 17, 2020 that All techniques, including simple computers, e-mail, teleconferencing, and video conferencing, are available to all judges and court clerks to continue handling judicial matters and other limitations in person. Appearances in the courtroom. Any criminal or civil laws that would obstruct the right of a court clerk or judge to use such technologies are hereby suspended until Friday, April 3, 2020, and possibly extended by this court's order as circumstances might warrant. (National Center for State Courts, 2020). 


\subsubsection{Ban on Entering the Court Area for Those Who Have Been Exposed to Covid-19}

Some courts in some states do not even delay the judicial process or stages nothing but ordered a ban on the presence entering the area of justice for those who have been exposed to Covid-19 (North Carolina Judicial Branch, 2020). for example, decomposes in judicial order Chairman of the North Carolina March 13, 2020, that the courts also order that the superior court clerks post a notice at the entrance to each court facility in their county directing that any person likely to have been exposed to COVID-19 should not enter the courthouse...(National Center for State Courts, 2020)

\subsubsection{Postponing Jury Trial Sessions}

Some Courts in several states do not even postpone the entire trial process but only delaying the jury trial session (oral argument) (Supreme Court of the State of Delaware, 2020). For example, it breaks down in Judicial Order the Delaware High Court March 15, 2020, that via and including April 15, 2020, all civil and criminal jury trials are postponed. Via and including April 15, 2020, Petit Jury duty is suspended. During this period, individuals summoned for petite jury duties are excused and do not appear. As instructed, Grand Jurors should write.

\subsubsection{Not Declaring a State of Emergency at Least}

There were four states up until April 6, 2020, namely Michigan, Nevada, Ohio, and South Dakota. All four consider that following the concept of Fiat justitia ruat coelum; justice is the manifestation of the authority of God over the expression of the sense of justice. (National Center for State Courts, 2020).

\subsection{How Court Administration in Indonesia and Germany Respond in Covid 19?}

The Indonesian government first declared a state of emergency through the National Board of Disaster Management (Badan Nasional Penanggulangan Bencana or BNPB) in response to the Covid-19 Pandemic. Not long after that, the President issued Presidential Decree No. 7 of 2020 concerning The Task Force for the Acceleration of Handling Corona Virus Disease (COVID-19) appointed BNPB as coordinator. Furthermore, responding to the worsening situation, the President issued Presidential Decree No. 11 of 2020 concerning Establishment of public Health Emergency Corona Virus Disease 2019 (COVID-19) on March 31, 2020. Regardless of various government actions in establishing emergencies, the response was considered not fast, indecisive, and seem to stutter. When referring to history when the Spanish Flu Pandemic in 1918, the Dutch East Indies government worked poorly in overcoming it and only relied on Ordonnant influenza which had just been published on October 20,1920, or two years after the pandemic spread from Europe to various countries, this condition resulted in many victims falling during the period 1918-1920 in the Dutch East Indies (National Center for State Courts, 2020).

Therefore, the Supreme Court and the Constitutional Court as the perpetrators of the judiciary, respond to this situation in different ways, even though many things are understandable because it has never happened before in the history of justice in Indonesia. The Supreme Court, for example, responded to the emergency of the Covid-19 pandemic by issuing the Circular of the Secretary of the Supreme Court (Surat Edaran Sekretaris Mahkamah Agung or SE SEKMA) No. 1 of 2020 concerning Adjustments to the Working System of Judges and Judicial Apparatuses in Preventing the Spread of COVID-19 in the Indonesian Supreme Court and the Judiciary Underneath. However, some argue that the SE SEKMA does not show the Supreme Court's firmness to prevent the spread of Covid-19. According to Point B No. 1 of SE SEKMA No. 1 of 2020 regulates that trials of criminal, military criminal and jinayat cases continue, as usual, even though this pattern has become a gathering place for many people, it has the potential to become a place for the spread of Covid-19. The existing opinion at that time considered that the Supreme Court did not consider the fact that the spread of Covid-19 was speedy and the death toll due to Covid-19 in Indonesia was increasing day by day (Covid-19.go.id, 2020). This will pose a risk of spreading Covid-19 to law enforcement officials such as judges, prosecutors, advocates and others who interact intensely in close range and physical contact with detainees. Finally, to respond to this, the Supreme Court in responding to the condition of the Covid-19 pandemic was to issue a Supreme Court Circular (Surat Edaran Mahkamah Agung or SEMA) No. 1 of 2020 concerning Guidelines for Performing Duties During the Prevention Period for Corona Virus Disease 2019 (Covid-19) in the Republic of Indonesia Supreme Court and the Agency The judiciary under it. This circular is considered to be the basis for justice concerning better law enforcement processes, especially in revising SE SEKMA No. 1 of 2020.

In SEMA No. 1 of 2020, there are classifications into 4 (four) forms of court policy, namely, first, trials of criminal, military and civil law cases continue to be carried out specifically for cases where the accused is being detained, and detention cannot be extended further. During the period of preventing the spread of Covid-19 within the Supreme Court and its subordinate judiciary. Secondly, the trial of criminal, military and jinayat cases against 
defendants who legally detained them for an extension, was postponed until the end of the Covid-19 deployment. Postponement of a trial can be carried out with a single judge. Third, for cases that are limited by the period of examination by statutory provisions, the judge may postpone even if the time limit exceeds the limit of the examination by the statutory provisions with an order to the substitute clerk to record in the Minutes of the Session that there are exceptional circumstances. Fourth, if there are cases which must still be heard, then:

1) Postponement of the trial and limitation of visitors to the hearing are the authority of the panel of judges to determine;

2) The panel of judges can limit the number and safe distance between visitors to the hearing (social distancing);

3) The Panel of Judges can order the detection of body temperature and prohibit physical contact such as shaking hands for parties who will be present or be presented at the trial;

4) The judges and parties in the trial can use protective equipment in the form of masks and medical gloves following the conditions and situation of the trial;

5) Justice seekers are encouraged to take advantage of applications e-litigation for civil, religious, and state affairs.

To date, SEMA No. 1 of 2020 has been changed three times through SEMA No. 2 of 2020, SEMA of No. 3 of 2020 and SEMA of No. 3 of 2020. SEMA of No. 2 of 2020 extends the duration of SEMA No. 1 of 2020 to April 21 2020, SEMA No 3 of 2020 extends SEMA No. 1 of 2020 to May 13, 2020, and SEMA No. 4 of 2020 extends SEMA No. 1 of 2020 to May 29, 2020. Elsewhere, the Constitutional Court has announced the closure of the building. From March 17 to April 21, 2020, by implementing work from home as well as submitting applications through simpel.mkri.id. Experienced by the author who is the Lawyer at Case No 23/PUU-XVIII/ 2020, Constitutional Court restricted the attendance of the parties to a hearing room of only five people, and the trial process required wearing masks and gloves along with body temperature measurements.

Despite the various responses of the Indonesian judiciary to Covid-19 through various policies, there are obvious weaknesses in the policy taken that the potential for diversity in judicial administration, for example, is the case in Supreme Court where SEKMA and SEMA submit policies that technically govern each judiciary. This condition indicates that Information Technology (IT) will support and ensure good governance and judicial processes need to be accelerated (Chandranegara, 2019). The era of the judicial process, where nepotism, conspiracy, and corruption undermines the power of justice (Pompe, 2012), cannot be repeated. Information Technology is required in the court process through video use, audio in conference sessions, electronic reporting, witness conference video, and file storage. In short, all decision-making processes at the conference require Information Technology (Pompe, 2012). Supreme Court and Constitutional Court have accommodated this with the use of technology to inform the administration of justice. Constitutional Court officially launches the Constitutional Court Information System consisting of Applications Online, Tracking Article, Constitutional Court Decision Annotations, e-Minutes, e$B R P K$ (electronic registration), Constitutional Court Visits, Live Streaming, and Remote Conference Services (video conference), and Supreme Court with The issuance of the Supreme Court Rule No. 3 of 2018 on the Case Management of Electronic Courts, thus fully Constitutional Court and Supreme Court embarked on a series of innovations and reforms of the justice system (Faiz, 2018). The dissociation factor is in line with what Richard Susskind proposes that the legal profession and trial need to adapt by leveraging technology into something relevant (Susskind, 2013).

Besides, if the situation has improved, it should be in the event law books to set the event law in jeopardy. About Germany, through Zivilprozeßordung (abbreviated as ZPO or the Civil Procedure Book), ZPO has regulated the law of events in an emergency through the Chapter on Interruption and suspension of the proceedings outlined in Article 239-225 of the ZPO. In connection with the Covid-19 condition, it is governed by Article 245 of the ZPO which defines "the event of war or any other event, the court cease its activities, the proceedings shall be interrupted for the duration of this situation. This condition confirms the legal context "the event of interruption due to suspension of the administration of law." Besides, the topic that needs to be discussed is how the judiciary needs to come up with a plan to exert its power over a long period in the event of Pandemic Covid-19. Implementation of the case management system and the judiciary will eventually need to be regulated in the event law of several courts or transformed into a single event law simultaneously. They can be enshrined in the future judiciary as a United States judicial emergency act. This need is needed to address similar challenges in the future.

\section{Conclusion}

Based on the above description, the conclusion for the first issue is that the state of emergency in the United States responded to the judiciary by implementing the Judicial Emergency Act of 2004 and delegating to each court the 
determination of its emergency policy and even able to legitimize each case and its policy in the Covid-19 Pandemic situation. As a result, there is a wide variety of court policies at both the state and the state. As for the second issue, the judiciary in Indonesia responded by arranging procedural technicals alone and delegating to the workforce leader to set more technical arrangements but without authorizing any case that needed to be dealt with on a regular or special basis.

According to these two factors, even though emergencies often focus on executive power. However, one thing to note is that the concept of the state of law continues to work. Its function is to prevent emergencies from achieving access to justice in the exercise of constitutional and legal rights. Therefore, the improvement of law of judiciary must be made that primarily governs the administration of justice in emergencies and the need for legal reforms in some jurisdictions in response to the Covid-19 hazard situation. Learning from other countries such as the United States and Germany, especially reviewing legal material in support of health emergencies, is a necessary step in the direction of legal reforms that provide protection even in times of crisis.

\section{References}

Arde-Acquah, P. E. (2015). Salus Populi Suprema Lex Esto: Balancing Civil Liberties and Public Health Interventions in Modern Vaccination Policy. Washington University Journal Review, 7, 337-366.

Bader, W. D., \& Williams, F. J. (2009). David Davis: Lawyer, Judge, and Politician in the Age of Lincoln. Roger Williams University Law Review, 14(2), 163-214.

Chandranegara, I. S. (2019). Kemerdekaan Kekuasaan Kehakiman Pascra Transisi Politik. Radjawali Press.

Chandranegara, I. S. (2020a). Diantara yang Terbaik dan Buruk dalam Merespon Covid-19 di Asia Tenggara. Surabaya State University.

Chandranegara, I. S. (2020b). Komparasi Kebijakan Hukum dalam Penanggulangan Pandemi Penyakit Menular (Covid-19) di Berbagai Negara: Penggunaan Keadaan dan Hukum Darurat atau Optimalisasi Instrumen Hukum yang ada? Faculty of Law Tarumanegara University, Faculty of Law Surabaya University, Jimly School Law and Government, Kolegium Jurist Institute.

$\begin{array}{lllll}\text { Covid-19 Updates and Information. } & \text { (2020). Retrieved }\end{array}$ www.mass.gov/files/documents/2020/04/03/12926.pdf

In the Court of Appeals of Maryland Administrative Order Extending the Length of Statewide Judiciary Restricted Operations Due to the Covid-19 Emergency. (2020). Retrieved from www.courts.state.md.us/sites/default/files/admin-orders/20200325extendinglengthofrestrictedoperations.pdf

Covid-19.go.id. (2020). Peta Sebaran. Retrieved from www.covid19.go.id/peta-sebaran

Faiz, P. M. (2018, April). MK and the E-Court in a Disruptive Era. Constitutional Magazine No. 134., 79-80.

Gerstein, J. (2020). Supreme Court postpones arguments due to coronavirus: cases on access to Trump's financial records are indefinitely postponed. Retrieved from www.politico.com/news/2020/03/16/supreme-courtpostpones-arguments-coronavirus-131881

Hawai'i State Judiciary. (2020). Chief Justice Issues Order Limiting In-Court Proceedings. Retrieved from www.courts.state.hi.us/news_and_reports/2020/03/chief-justice-issues-order-limiting-in-court-proceedings

Hiatt, L. A. (2020). Supreme Court issues new amendments with ordering limiting in-person court proceedings, extends restrictions to April 24. Retrieved from www.kentucky.gov/Pages/Activitystream.aspx?n=KentuckyCourtofJustice \&prId=164

Hunter, N. D. (2017). The Law of Emergencies Public Health and Disaster Management. Elsevier and Butterworth.

In the Matter of Ongoing Preparation for Coronavirus/Covid-19 Impact on Court Services, 13. (2020). Retrieved from www.iowacourts.gov/static/media/cms/Supervisory_order_of_3142020_22BCE0F4943C5.pdf

Libowitz, J. (2020). Trump enables Jared Kushner's coronavirus task force, revealing the dangers of nepotism. Retrieved from www.nbcnews.com/think/opinion/trump-enables-jared-kushner-s-coronavirus-task-forcerevealing-dangers-ncna1176511

Liptak, A. (2012, February). Justices Asked Whether Decision on Deportation Warnings Applies Retroactively. New York Times, 16.

Livni, E. (2020). The coronavirus crisis is forcing the US Supreme Court to face its technology problem. Retrieved from www.qz.com/1832572/coronavirus-crisis-forces-scotus-to-face-its-technology-problem

For Immediate Release. (2020). Retrieved from https://courts.mt.gov/Portals/189/docs/COVID-19 3-17.pdf 
National Center for State Courts. (2020). Coronavirus Orders/ Domestic Violence Protection. Retrieved from www.ncsc.org/ /media/Files/PDF/Newsroom/Coronavirus-Orders/Domestic-violence-protectionorders/Alabama 3-13-2020 COV-19 order FINAL.ashx

Nevada Judiciary. (2020). Nevada Judiciary. Retrieved from www.nvcourts.gov/

New Mexico Courts. (2020). New Mexico Courts. Retrieved from www.nmcourts.gov/uploads/FileLinks/a6efaf23676f4c45a95fdb3d71caea83/News_Release_ NM_Courts_ to_remain_open_despite_school_closures.pdf

New York Courts. (2020). Coronavirus and The New York State Courts. Retrieved from www.nycourts.gov/index.shtml

North Carolina Judicial Branch. (2020). Chief Justice Beasley Issues Order Postponing Court Proceedings Until June 1, 2020. Retrieved from www.nccourts.gov/news/tag/press-release/chief-justice-beasley-issues-orderpostponing-court-proceedings-until-june-1-2020

Oregon State Courts. (2020). Responses to Coronavirus (COVID-19). Retrieved from www.courts.oregon.gov/courts/Pages/coronavirus.aspx

Pimentel, D. (2015). Reframing the Independence v. Accountability Debate: Defining Judicial Structure in Light of Judges' Courage and Integrity. Cleveland State Law Review, 51(1), 1-34.

Pompe, S. (2012). Runtuhnya Institusi Mahkamah Agung. LEIP.

Rheinstein, M. (1968). Comparative Law - Its Functions, Methods and Usages. Arkansas Law Review, 22(3), 415 425.

Sarat, A. (2020). Coronavirus: Will courts continue to operate, preserving the rule of law?. Retrieved from www.theconversation.com/coronavirus-will-courts-continue-to-operate-preserving-the-rule-of-law-134084

Sheeran, S. P. (2013). Reconceptualizing the States of Emergency under International Human Rights Law: Theory, Legal Doctrine, and Politics. Michigan Journal of International Law, 34(3), 491-557.

State of Connecticut Judicial Branch. (2020). Covid-19 Information from Connecticut Judicial Branch. Retrieved from www.jud.ct.gov/COVID19.htm

State of Indiana. (2020). COVID-19 Responses and Resources. Retrieved from www.in.gov/judiciary/5575.htm

State of Maine Judicial Branch. (2020). Coronavirus 2019 (COVID-19) Information. Retrieved from www.courts.maine.gov/covid19.shtml

Continuing Operations of the Courts of the State of Minnesota Under a Statewide Peacetime Declaration of Emergency, Pub. L. No. ADM20-8001. (2020). Retrieved from https://www.mncourts.gov/mncourtsgov/media/CIOMediaLibrary/Administrative-Order-Continuing-theOperations-of-the-Courts.pdf

State of North Dakota Courts. (2020). Emergency Order and Pandemic Response. Retrieved from https://www.ndcourts.gov/emergency-order-and-pandemic-response

Administrative Order. (2020). Retrieved from http://www.alacourt.gov/docs/Administrative Order No. 5.pdf

Re: Judicial Emergency Declared, Amended Order, 2. (2020). Retrieved from www.courtswv.gov/covid19/JudicialEmergencyDeclaredAmendedOrder4-3-20.pdf

In Re Response to The Covid-19 Pandemic, 2. (2020). Retrieved from https://www.arcourts.gov/sites/default/files/articles/COVID-19-PC-april-3.pdf

State Wide Order by the Chief Justic eChair of the Judicial Council. (2020). Retrieved from www.newsroom.courts.ca.gov/internal_redirect/cms.ipressroom.com.s3.amazonaws.com/262/files/20202/St atewide $\% 2520$ Order $\% 2520$ by $\% 2520$ the $\% 2520$ Chief $\% 2520$ JusticeChair\%2520of $\% 2520$ the $\% 2520$ Judicial $\% 2520$ Council\%25 203-23-2020.pdf

Cases of Interest/Order Extending Prohibition on Jury Calls. (2020). Retrieved from https://www.courts.state.co.us/userfiles/file/Media/SC - Cases of Interest/Order Extending Prohibition on Jury Calls.pdf

In Re: Covid-19 Emergency Measures in the Florida State Courts, Pub. L. No. AOSC20-17. (2020). Retrieved from www.floridasupremecourt.org/content/download/632431/file/AOSC20-17.pdf

CJ Melton amended Statewide Judicial Emergency Order. (2020). Retrieved from www.gasupreme.us/wp- 
content/uploads/2020/03/CJ-Melton-amended-Statewide-Jud-Emergency-order.pdf

Illinois Courts Response to COVID-19 Emergency Impact on Trials, Pub. L. No. M.R. 30370. (2020). Retrieved from https://courts.illinois.gov/SupremeCourt/Announce/2020/040320.pdf

Supreme Court of Louisiana. (2020). Press Releases. Retrieved from www.lasc.org/press_room/press_releases/2020/2020-04.asp

Formatted Order. (2020). Retrieved from www.courts.michigan.gov/Courts/MichiganSupremeCourt/rules/courtrules-admin-matters/Administrative Orders/2020-08_2020-03-15_FormattedOrder_AO2020-1.pdf

In Re: Emergency Order Related to Coronavirus (COVID-19), Pub. L. No. 2020-AD-00001-SCT, 3. (2020). Retrieved from https://courts.ms.gov/appellatecourts/docket/sendPDF.php?f=700_490703.pdf\&c=91465\&a=N\&s=2

Supreme Court of Missouri. (2020). No Title. Retrieved from www.courts.mo.gov/page.jsp?id=153953

Order Suspending In-Person Court Proceedings, 3. (2020). Retrieved from www.courts.state.nh.us/supreme/orders/3-16-20-order.pdf

Supreme Court of New Jersey. (2020). State Court Closing Information. Retrieved from www.njcourts.gov/courts/closings.html

Supreme Court of Oklahoma. (2020). SCAD. Retrieved from www.oscn.net/images/news/SCAD-2020-24.pdf

In Re: The Petition of the Pennsylvania Prison Society, Brian Mchale, Jeremy Hunsicker, Christopher Aubry, Michael Foundos, and Frederick Leonard, on Behalf of All Similarly Situated Individuals, Pub. L. No. 70 MM 2020. (2020). Retrieved from www.pacourts.us/assets/files/page-1305/file-8910.pdf

In Re Request for Prison Census Control. (2020). Retrieved from www.courts.ri.gov/PDF/InreRequestforPrisonCensusControl(Order).pdf

Supreme Court of South Carolina. (2020). What's New. Retrieved from www.sccourts.org/whatsnew/displaywhatsnew.cfm?indexID=2474

Supreme Court Declares a Judicial Emergency in South Dakota. (2020). Retrieved from www.ujs.sd.gov/uploads/news/JudicialEmergencyCOVID19.pdf

Order Continuing Suspension of In-Person Court Proceedings and Extension of Deadlines. (2020). Retrieved from www.tncourts.gov/sites/default/files/docs/order_-_2020-03-25t120936.486.pdf

First Emergency Order Regarding the Covid-19 State of Disaster. (2020). Retrieved from https://www.txcourts.gov/media/1446056/209042.pdf

In Re Court Operations and Proceedings in Response to Novel Coronavirus Disease, Pub. L. No. 2020- ADM0005- MSC. (2020). Retrieved from www.nmijudiciary.com/wp-content/uploads/2020/04/Covid-Order-No21.pdf

Special Order to the Chief Justice. (2020). Retrieved from https://public.courts.alaska.gov/web/covid19/docs/socj2020-8131.pdf

In the Matter of Authorizing Limitation of Court Operations During A Public Health Emergency, Pub. L. No. 2020-48. (2020). Retrieved from www.azcourts.gov/Portals/22/admorder/Orders20/2020-48.pdf

Order Declaring Judicial Emergency, 3. (2020). Retrieved from https://courts.delaware.gov/forms/download.aspx?id=120328

In Re: Idaho Supreme Court Response to Covid-19 Emergency. (2020). Retrieved from https://isc.idaho.gov/EO/ISC-Emergency-Order-Ammended.pdf

In The Supreme Court of The State of Kansas, Pub. L. No. 2020-PR-32, 12. (2020). Retrieved from https://www.kscourts.org/KSCourts/media/KsCourts/Orders/2020-PR-032.pdf

In Re Novel Corovairus and Covid-19 Disease, 2. (2020). Retrieved from https://supremecourt.nebraska.gov/sites/default/files/Administration/emergency/order3.12.20.pdf

Supreme Court of Utah. (2020). Alerts. Retrieved from www.utcourts.gov/alerts/

Order Extending Declaration of Judicial Emergency. (2020). Retrieved from www.courts.state.va.us/news/items/2020_0327_scv_order_extending_declaration_of_judicial_emergency.p df 
$\begin{array}{llll}\text { Supreme } & \text { Court } & \text { (2020). } & \text { Retrieved }\end{array}$ www.courts.wa.gov/content/publicUpload/SupremeCourtOrders/SupremeCourtEmergencyOrderreCV1903 1820.pdf

Superior Court of the District of Columbia. (2020). Retrieved from www.dccourts.gov/sites/default/files/mattersdocs/General Order pdf/Amended-Order-5-14-20.pdf

COVID-19 Order Extend Temporary Plan. (2020). Retrieved from www.courts.state.wy.us/wpcontent/uploads/2020/04/COVID-19-Order.Extend.temp_.plan_.pdf

Susskind, R. (2013). Tomorrow's Lawyers: An Introduction to Your Future. Oxford University Press.

The Supreme Court of Ohio. (2020). Coronavirus Resources. Retrieved from www.supremecourt.ohio.gov/coronavirus/default.aspx

$\begin{array}{llll}\text { Judicial } & \text { Emergency } & \text { Act. } & \text { (2004). }\end{array}$ https://www.csg.org/knowledgecenter/docs/pubsafety/JudicialEmergencyAct.pdf

Temporary Postponement of Jury Trials. (2020). Retrieved from www.vermontjudiciary.org/sites/default/files/documents/ADMINDIR36.pdf

Walsh, M. (2020). Outbreaks of disease have shuttered the Supreme Court going back more than two centuries. Retrieved from www.abajournal.com/web/article/outbreaks-have-shuttered-the-supreme-court-going-backmore-than-two-centuries

Wisconsin Court System. (2020). Message from the Chief Justice. Retrieved from www.wicourts.gov/

\section{Copyrights}

Copyright for this article is retained by the author(s), with first publication rights granted to the journal.

This is an open-access article distributed under the terms and conditions of the Creative Commons Attribution license (http://creativecommons.org/licenses/by/4.0/). 